\title{
Georges Didi-Huberman, Écorces, and Otto Dov Kulka, Landscapes of the Metropolis of Death - as Lager essays? Imagination and remembrance of the title formulations in relation to the formulation "anus mundi"
}

\begin{abstract}
The sites I saw were disfigured, effaced. They were non-sites of memory (non-lieux de la mémoire).

The places no longer resembled what they had been. ${ }^{1}$
\end{abstract}

\section{Record}

I would like to begin with a reference to the basic topic of the periodical, in which the word record seems the most intriguing. That formulation has already been discussed by Lager, Gulag, and camp researchers. Arkadiusz Morawiec, and Lesław M. Bartelski ${ }^{2}$ before him, referred to the type of records, i.e. post-camp narratives, differentiating first-person and third-person ones. Morawiec wrote:

In the case of a consistent usage of first-person narrative, the author [applied to Seweryna Szmaglewska and Smoke Over Birkenau - note by KKK] - wanting to maintain a pretence of objectivity - would have to document her extensive knowledge of the camp each time, which she could not have gained through her own experience (of over two years' internment at a Lager), i.e.: be everywhere. She did, in fact, mention in the introduction her "long internment at Birkenau" [...], yet a large portion of the information included in the book must have been second-hand knowledge. It would be difficult to assume that the author witnessed herself an orgy of SS men, that she visited men's barracks, or observed up close the burning of corpses in pits in Birkenau. Thus, the panoramic image of the camp in Auschwitz included in the first-person recollections in Anus mundi by Wiesław Kielar seems no less convincing, objective, or reliable. He was more "ubiquitous" than Szmaglewska. He spent over four years in Auschwitz-Birkenau. As a prisoner,

* Professor; European Traditions Study Centre, Institute of Polish Philology, Adam Mickiewicz University in Poznań; eadem@amu.edu.pl.

${ }^{1}$ Claude Lanzmann's Shoah. Key Essays, S. Liebman, Oxford University Press, New York 2007, p. 39. As cited in: P. Czapliński, "Nie-miejsce" [entry] in: Modi memorandi. Leksykon kultury pamięci, M. Saryusz-Wolska, R. Traba (eds.), collaborator J. Kalicka, Scholar, Warsaw 2014, p. 272. Cf. also: C. Lanzmann, "Le non-lieux de la mémoire", in: Au sujet de Shoah, le film de Claude Lanzmann, B. Cuau (ed.), Belin, Paris 1990, pp. 280-293.

${ }^{2}$ L.M. Bartelski, “Zapis zbrodni”, in: ibid.: Cień wojny. Eseje, Czytelnik, Warsaw 1983. 
he went through several levels of the camp ladder: he was a corpse carrier, he pulled out the corpses of Soviet POWs gassed in one of the blocks, he was a kapo, a writer (Schreiber), he worked in various kommandos, and he spent twenty nights in a Stehbunker, a standing cell. Yet what seemed most important was that female internees had less freedom to move around a Lager due to a smaller spectrum of employment opportunities. Thus a question arises whether almost solely indirect narration of Smoke..., visible in the direct expressions by the narrator to a more or less concrete you, usually a co-internee, was not, paradoxically, less objective and reliable than a first-person narration. Such a doubt can be found in Tadeusz Borowski's stipulation towards Zofia Kossak, the author of a Birkenau memoir entitled $Z$ otchtani: «one cannot write indirectly about Oświęcim» [a quote from the famous review entitled "Alicja w krainie czarów" [Alice in Wonderland], Pokolenie 1947, issue 1, p. 9 - note KKK]. ${ }^{3}$

Further in the text it will become evident why that rather lengthy quote is so important. For now, let me quote, to my own surprise, Stanisław Lem, who in "Terminus" (in the Opowieści o pilocie Pirxie series) wrote: "One thing is certain: that record, if it is a record at all, is not dead. Whoever those people - the voices, the strikes - are, it is possible to talk to them. If one is only brave enough..." Those words could be referred to many camp, Lager, or Gulag writings, which we as literary scientists, historians, or, more broadly, humanists call (to quote Roman Zimand) personal document literature, ${ }^{5}$ and, to quote Jerzy Jedlicki, we strive to organise them as "experienced stories" and/or "testified history". ${ }^{6}$

In my study, however, I propose something different. I propose to delve deep into the oxymoron which the formulation of Lager essays seems to be. Extermination essays are already rare. Primo Levi, Jean Améry, ${ }^{7}$ Maurice Blanchot, ${ }^{8}$ Bogdan Dawid Wojdowski. ${ }^{9}$ There are not too many of those. They possess a roughly discussed specificity. ${ }^{10}$ Lager-related? I.e. some special variant of location essays, or geo-essays? Or maybe the act of trying (from the French essayer) non-site? ${ }^{11}$

${ }^{3}$ A. Morawiec, Literatura w lagrze, lager w literaturze. Fakt-temat-metafora, Wydawnictwo Akademii Humanistyczno-Ekonomicznej, Łódź 2009, pp. 189-190.

${ }^{4}$ As cited in: A. Gajewska, Zagłada i gwiazdy. Przeszłość w prozie Stanisława Lema, Wydawnictwo Naukowe UAM, Poznań 2016, p. 212. [Unless otherwise indicated, the English versions of all texts originally in Polish were translated from Polish]

${ }^{5}$ R. Zimand, Diarysta Stefan Ż., Ossolineum, Wrocław 1990.

${ }^{6}$ J. Jedlicki, "Dzieje doświadczone i dzieje zaświadczone", in: Dzieło literackie jako źródło historyczne, Z. Stefanowska and J. Sławiński, Czytelnik, Warsaw 1978, pp. 344-371.

${ }^{7} \mathrm{I}$ am referring in particular to the essay entitled Mein Judentum, as well as the Jenseits von Schuld und Sühne and Über das Altern collections.

${ }^{8}$ Cf. M. Blanchot, Niezniszczalne. Być Żydem, trans. W. Błońska, Literatura na Świecie 1996, issue 10, pp. 59-68.

${ }^{9}$ B. Wojdowski, "Judaizm jako los", Puls 1993, issue 3. More on the subject, cf. K. Kuczyńska-Koschany, "Eseiści kondycji żydowskiej - po Zagładzie: Maurice Blanchot i Bogdan Dawid Wojdowski”, Poznańskie Studia Polonistyczne. Seria Literacka, vol. 30 (2017), pp. 385-399.

${ }^{10}$ More on the subject, vide A. Ubertowska, Holokaust. Auto(tanato)grafie, Wydawnictwo IBL PAN, Warsaw 2014.

${ }^{11}$ More on the subject, vide P. Czapliński, Nie-miejsce, pp. 270-272. Czapliński called non-site "a category of the anthropological scope over space" (p. 270), defined, i.a. in relation to memory 
Two thinkers (I am not referring to them as philosophers on purpose) decided, independently of each other, to record the experience of the space of a Lager, one which is unrecordable yet which defines the borderlines of imagination. The essays by Otton Dov Kulka (born in 1933) from the Landscapes of the Metropolis of Death collection, and Écorces by Georges Didi-Huberman (the author of Images malgré tout $)^{12}$ entered into a creative debate with the title formulation of the book by Wiesław Kielar (1919-1990) Anus mundi, published in 1966 (date of completion recorded by the author was 21 January 1966). ${ }^{13}$ They did that in two different manners, between which, however, one could notice a certain tertium comparationis - a reverse approach in relation to the "anus of the world". They tried to write an essay, i.e. something just as strange as (once for Adorn) a poem, a poem by Paul Celan, after Auschwitz.

\section{Anus mundi}

The formulation itself of anus mundi has an interesting, and possibly not widely known story to it. In the introduction to Wiesław Kielar's book (bear in mind: Auschwitz internee No. 290, i.e. one of the earliest numbers in Auschwitz among those who survived), one could read that it was Birkenau/Brzezinka that an SS doctor Hauptsturmführer Thilo called the "rectum of the world" (upon selecting and putting to death 800 women):

That opinion, he continued, was recorded by his colleague Johann Paul Kremer, also an SS doctor, a university professor, doctor of medicine and philosophy, under the date 5 September 1942 as he wrote verbatim: “Today at midday during a special operation from the women's

and individual identity. The Poznan anthropologist developed that notion based on Thomas More (Utopia, 1516), who differentiated between the Greek ou-tópos and eu-tópos; he indicated Michel de Certeau as being the first to use the term non-lieu, in a work entitled The Practice of Everyday Life (1980), that special proper name of a "hollow or non-site bored by the law of another", overburdened with individualised memory, and untameable. Another well-known usage of the term was an essay by Marc Augé entitled Non-Places: Introduction to an Anthropology of Supermodernity (1995), who "thus called places devoid of memory, and which do not constitute the locum of authorities, and yet which are untameable, and not supporting general sovereignty". For my discussion, most important is Czapliński's remark: "Within the polemic with Pierre Nora's concept (and independently of Augé's reflection), Claude Lanzmann concluded that when he arrived at former concentration camps, he found «non-sites of memory» [...] «The sites I saw were disfigured, effaced. [...] The places no longer resembled what they had been». [...] it is possible that Lanzmann referred to the radical inability of a camp/place of memory to bring back memories, i.e. indicate the meanings of the central site, which in a camp was the gas chamber, and help realise the difference between the space of life outside the camp, and the space of death inside it" (p. 272, bolding KKK)

${ }^{12}$ G. Didi-Huberman, Obrazy mimo wszystko, trans. M. Kubiak Ho-Chi, Universitas, Krakow 2008.

${ }^{13} 1^{\text {st }}$ edition $-1966,2^{\text {nd }}$ edition $-1972,3^{\text {rd }}$ edition -1980. 
camp: an utter atrocity. Hauptsturmführer Thilo, the garrison doctor, was right when he told me today that we are at anus mundi (the rectum of the world). ${ }^{14}$

Mieczysław Kieta, the author of the introduction to Kielar's book, thus explained the formulation uttered during the mass killing referring to Antoni Kępiński's words:

Anus mundi as uttered by the garrison doctor SS Heinz Thilo was for that place a term expressing, on the one hand, the disgust and terror which a concentration camp evoked in anyone who saw it [...], and, on the other, it justified the existence of the camp with the need to cleanse the world. Within the concept of a Nazi death camp - apart from the direct political-economic goal consisting of the most effective and cost-efficient method of exterminating the enemy - it had a deeper sense; that was to cleanse the German race of anything that did not correspond to the ideal of a German Übermensch (AM, 13-14).

The first printed version of Kępiński's text entitled Anus mundi appeared in Przeglad Lekarski in 1965, issue 1. While Mieczysław Kieta stated that the title Anus mundi "was accepted by the Publishing House as the title of Kielar's memoir" - also (not exclusively) - because "it offered the most concise expression of the functions of a Nazi death camp". (AM, 14) Therefore, the anus mundi formulation was not Kielar's original choice, as it resulted from Kępiński's reflection, who wrote that "Death camps revealed the truth about man, which humanity has not yet been able to digest" (RO, fourth cover page).

In Kępiński's Refleksje oświęcimskie, published in 2005 and edited by Zdzisław Jan Ryn, there are two major thematic parts:

The first one entitled Anus mundi includes articles devoted to camp reality, and its traumatic outcomes. They were printed during the author's life, and later collected in a book entitled Rytm życia. The second part, Homo homini lupus est, includes articles with a broader thematic scope $[\ldots]$, and two unpublished typescripts from the 1960s. ${ }^{15}$

In an article entitled Anus mundi, Antoni Kępiński referred to that term as being "blunt", and wrote, e.g.:

Within the Nazi concept, death camps - apart from the direct political-economic goal consisting of the most effective and cost-efficient method of exterminating the enemy - they had a deeper sense; that was to cleanse the German race of anything that did not correspond to the ideal of a German Übermensch. It carried the distant vision of a world of beautiful humans, strong and healthy, a world where there would be no place for the sick, disabled, mentally abnormal, tainted with Jewish or gypsy blood.

${ }^{14}$ W. Kielar, Anus mundi, $3^{\text {rd }}$ edition, Wydawnictwo Literackie, Krakow 1980, p. 13. Hereinafter as AM, with a page number. Cf. also: W. Sofsky, Die Ordnung des Terrors. Das Konzentrationslager, S. Fischer, Frankfurt am Main 1993.

${ }^{15}$ Z.J. Ryn, "Wstęp", in: A. Kępiński, Refleksje oświęcimskie, selection and introduction Z.J. Ryn, Wydawnictwo Literackie, Krakow 2005, p. 8. Hereinafter as RO, with a page number. 
For that "beautiful" goal, it was necessary to proceed through horrible atrocities of concentration camps. No wonder, then, that service at a camp was considered equal to service at the front, though SS men probably preferred to be heroes in a camp than at the front. The principle of remaining alive is usually stronger than ideology; even better when proud ideology helps justify one's cowardice. Yet there were also some, however few, who could not bear the debasement of the service at a camp, and chose the front or suicide. The majority calmed their consciences with alcohol, and a sense of fulfilled duty for the good of the homeland, and the grand idea $(\mathrm{RO}, 11-12)$.

Kępiński indicated that those "who were the obstacle, material designated for extermination, so that they would not contaminate the new world any more" were differently disposed towards the principles of that world: either fatalistically as irreversible fate, or pragmatically as an opportunity to emulate with a horizon a possible survival, or different still - for that rarest attitude I cannot find the right term, therefore I quote:

There were also those who despite the hunger, thirst, cold, pain, and humiliation were able to somewhat distance themselves from their suffering, and not to think only about finding something to eat, in order to stop feeling cold or hot, for the tormented body to stop aching. The biological imperative is extraordinarily strong, and it requires a strong will not to think about bread when you are hungry, about water when you are thirsty, or about an aching place when in pain. That effort was, in fact, necessary to maintain internal freedom - a free space where you could think, dream, and plan freely, associate decisions, and liberate yourself from the horror of the present. If in camp life, in that anus mundi, there was so much sacrifice, courage, and love for man, i.e. phenomena which in those conditions, it would seem, were virtually impossible, it was so thanks to that internal freedom $(\mathrm{RO}, 15)$.

Personal document literature offered the basis for a paraphrase of the expression anus mundi in the title of a historical work. A monograph by Zygmunt Zonik, a Buchenwald internee, who participated in the death marches, a researcher and a documentary film-maker, which described the evacuation and the liberation of Lagers, published in 1988, was entitled Anus belli (rectum of war). Zonik did not refer to Kielar in any location of his book which exceeded four hundred pages. He only wrote that "they did not have to kill", meaning the final acts of the oppressors, and the killing of tens of thousands of war victims. The similarity of the titles is, however, deeply intriguing, and it resulted not only, I believe, from pre-WWII education with its obligatory knowledge of Latin in combination with personal and long-term camp experience. ${ }^{16}$

They, i.e. both formulations: anus mundi, and anus belli, are semantically related to Joseph Conrad's "heart of darkness", ${ }^{17}$ and yet extremely different from

${ }^{16}$ Z. Zonik, Anus belli. Ewakuacja i wyzwolenie hitlerowskich obozów koncentracyjnych, PWN, Warsaw 1988.

${ }^{17}$ Vide J. Conrad, Heart of Darkness, Penguin Books, London 1994. 
it as they refer to an area which had rather been tabooised than subjected to metaphorisation. In thinking about the "heart of darkness", we can continue to foster the aesthetic illusion of Europeans or an illusion of an illusion (today, in the post-colonial epoch, we are not doing that any more, yet it lasted long before we started thinking about the genocide in Africa as genocide in this world, not some other world); when one reads the title - anus belli or anus mundi - there is no question of any illusions.

And that was what struck me - how is an essay, the area of nuance par exellen$c e$, related to that? Who speaks when an essayist speaks? It was not the motifs of the originators or the victims that were sought after by Kępiński, Kielar, Borowski, or Szmaglewska. Nor, not completely in any case, the witness. Who then? And how can she/he be still someone else? And why in both selected essays, are two words incessantly repeated: memory and imagination?

\section{Écorces}

Paul Celan, whose Todesfuge caused probably the biggest debate on the appropriateness of writing poems after Shoah, a debate between a poet and a philosopher, from which poetry emerged victorious, though changed, also the poetry of Celan himself, whose parents died in the Romanian camp of mass extermination in Transnistria, ${ }^{18}$ wrote that poems are a slightly better bark of plane trees. He also indicated the particular feature of the bark of those trees which look as if wounded. Somewhat similar features were assigned by Georges Didi-Huberman to the bark torn off of birches in Birkenau: "I looked at those three scraps of bark as if at three letters of a pre-alphabet writing"; "three scraps with grey, almost white surface", "pink like flesh", falling off in rolls as if the remnants of a burnt book. ${ }^{19}$

Écorces asks synecdochally about the history of killing, about the presence of the unimaginable in the organic: a theoretician who is helpless writes an essay. At the beginning of the essay, he studies the texture of the bark (mortal matter), to eventually write about issues of exceptional importance - he indicates another "image against all odds":

What the bark tells me about the tree. What the tree tells me about the forest. What the forest, a birch forest, tells me about Birkenau. That image, of course, just like the other ones, is just a trifle. A trifle, a superficial trifle: a film, depositing silver halides, materialising pixels. Everything always on the surface, layered. Technical surfaces indicating only the surface of things. What does it tell about the depths, what depths does it reach? Most images - I'm aware of that - remain without any consequences. [...]

${ }^{18}$ More on the subject, vide T. Snyder, Black Earth. The Holocaust as History and Warning, Tim Duggan Books, New York 2015.

${ }^{19}$ G. Didi-Huberman, Kora, trans. T. Swoboda, W podwórku, Gdańsk 2013, p. 7-8. Hereinafter referred to as K, with a page number. [English version translated from Polish] 
Not all images, though, remain without consequence for others. There are also those - like the images made by a member of Sonderkommando at Birkenau - which turn out to be a collective act, not just a regular private trophy or trinket. There are sometimes surfaces which change the depths of the surroundings. Philosophers of pure ideas, mystics of the Saint of the Saints think about the surface only as make-up, a lie: that which conceals the true essence of things. So pretence vs. the essence, appearance vs. substance. But you could also say that a substance existing outside the surface is only a metaphysical illusion. You could say that the surface is something that falls off of things: which comes directly from them, separates from them, so originates in things. And which separates in order to come and meet us, stand before our eyes, as if a scrap of bark. If only we decide to bend down to lift a few pieces (K, 85-87, bolding GDH).

What happens at the end of Didi-Huberman's essay is key to touch (exactly that, touch, not understand or settle) the experience of Shoah, and a Lager being that non-site where it also occurred. Suddenly it turns out that "The bark is no less real that the trunk" $(\mathrm{K}, 87)$, that it is "irregular, non-continuous, diverse", it is impurity, accidentality, diversity, abundance, relativity - and yet it comes from the essence of things. At that point there appear fundamental expressions in relation to the topic of the "record": bark, according to the essayist, "is located somewhere between the elusive pretence and surviving record. Or, in fact, it means a recorded pretence, the entire elusiveness of our life's decisions, our active and passive experiences." $(\mathrm{K}, 88)$ A few almost random photographs - neither revelation nor dejection - thus Didi-Huberman perceived his disposition at Birkenau. Suddenly: those photographs prove almost random ("A few images are nothing for such a story", $\mathrm{K}, 90$ ). The essayist explained the meaning of that almost/although:

For my memory they are, though, like a few scraps of bark: pieces of skin, a body. According to etymologists, the French word écorce is a mediaeval extension of the Latin scortea, meaning "a leather coat". [...] Classical Latin made a valuable differentiation: there is not one skin, but two. First, there is the epidermis, i.e. cortex. It is the outer part of a tree, which we cut off, "decork" first. The Indo-European core of the word - present in the Sanskrit words krtih and $k r t t i h$ - refers both to skin and a knife, which wounds it or cuts it off. In that sense bark signifies the borderline part of the body, vulnerable first to strikes, wounding, cutting off, and removal.

Then, as a designation of the place where it adheres to the trunk - which corresponds to dermis - Latin created another word revealing another facet of the first one: it is liber, meaning part of bark, which is better than cortex as a material for writing. Therefore, the word somewhat naturally offered the name for the things necessary for recording the scraps of our memories: things built of only surfaces, of cut up pieces of cellulose pressed from trees, on the surface of which there will appear words and images. Those are things falling out of our thought known as books. Things falling off during peeling off the skin, the bark of harmonised texts and images (K, 90-91, bolding KKK).

Finding the site within a non-site was achieved in the most painful way by the French essayist. The fact it would be possible in an attempt, thanks to an essay, was no prior knowledge, offered in advance, no assumption. The essay is, obviously, the highest risk of recording, it is assumptionless, and inconclusive. And in addition 
to that: amorphous. So it offers no support. It demands, in turn, extreme and detailed, sometimes report-like, honesty towards oneself:

I entered the main guardhouse. I photographed the windows overlooking the selection ramp. My friend Henri who accompanied me, and whose mild persistence induced me to make this trip, claims that I said: "It's unimaginable". I said that, of course, I said that like everyone does. Yet if I am to continue to write, view, frame, photograph, develop photographs, and think about it all, I will do it exactly to make that sentence incomplete. It would be necessary to say: "It is unimaginable so I must imagine it regardless". To, at least, present something, with a minimum of that which we can know about it

I watched, it was unimaginable, and yet so simple (K, 36-37, bolding KKK).

That "unimaginable" and "yet so simple", which one has to imagine regardless, enables one to notice the most important things:

It is completely different in Birkenau [than in Auschwitz - note KKK]. Here, there are almost no walls left. Yet the scale cannot lie, and it strikes with incredible force - a force of terror and despair. The earth cannot lie either. Auschwitz is becoming more like a museum today while Birkenau remains only an archaeological site. Or at least that is the impression it makes when we look at what can still be seen, where everything was destroyed: for example cracked, wounded, riddled, broken surface. It is a cut, mauled, opened surface. It is a scratched devastated surface, it is a surface which evokes screams.

Such a place requires the visitor to consider at some point her/his own act of watching (K, 31-32).

\section{Imagination afterwards}

The records by Otto Kulka, an Auschwitz survivor, "a child of the Lager”, are different. His memory and imagination corrected each other.

Yet both, Didi-Huberman and Kulka, went to Birkenau. The latter identified the features of a place in which he once had been, but as a different person:

But it was no longer the Metropolis of Death that it had been. It was a very melancholy landscape. A landscape fraught with desolation. But everything was there, but at a kind of distance. At a distance of desolation, but very searing. [...] Auschwitz had been buried. Buried but nonetheless expansive, like a kind of vast grave from horizon to horizon. But everything was there, and I, at least, was able to recognise it. ${ }^{20}$

Muteness and desolation. A piece of a crematorium brick, "black and sooty" (PMŚ, 28). "It was impossible to enter the gas chamber, because the roof had collapsed into it and blocked the entrance", (PMŚ, 30) wrote the essayist. In front of Birkenau's gate, a random taxi driver takes of photo of him with his Leica, his

${ }^{20}$ O.D. Kulka, Pejzaże metropolii śmierci. Rozmyślania o pamięci $i$ wyobraźni, trans. M. Szczubiałka, Czarne, Wołowiec 2014, p. 25. Hereinafter as PMŚ, with a page number. [English version: Kulka, D.O. Landscapes of the Metropolis of Death. Harvard University Press 2013] 
partner in his travels through the landscapes of the metropolis of death. At that point, he makes a special confession:

In the plane, which tossed back and forth - it was a small plane - I wrote some mad things in my diary that I always carry with me. I also wrote them in a letter; I don't know if the letter still exists (PMŚ, 31, bolding KKK).

That is a particular difference between Didi-Huberman, whose family partly perished in Shoah, and Kulka, who reproduced the images from his Theriesenstadt family camp, of small death, and how it was related to the great death, a scene of flogging as a ritual of the "system of everyday life", images from a camp of spectres - Auschwitz of the autumn of 1944/winter of 1945. He was prisoner to old landscapes, thus the inability to record, maintained in a series: "mad things" in his diary - a letter - an essay:

I remained in that Metropolis, a prisoner of that Metropolis, of that immutable law which leaves no place for being rescued, for violating this terrible 'justice' by which Auschwitz must remain Auschwitz. Thus the immutable law remained for me and thus did I remain caught up within it, which was actually what I discovered when I returned decades later. In that return, with the completion of the last act, which I had not then been 'privileged' to experience - the act of descending into the ruins that survived, at least to those of the gas chamber and the crematorium - that immutable law ran its course, $[\ldots]$ the "crowning glory was restored" and closes the odyssey in which I remained yoked and bound to that place (PMŚ, 66, bolding KKK).

Maybe the main feature of Kulka's essay is its amorphism. One which is visible in the richness of forms, their excess. Poems, prose, memoir fragments, report fragments, dated notes of various types and various locations, dream-like and experienced while being awake, identified through their titles. In a word: redundancy. In the case of Didi-Huberman, one has the impression of layering particles, overlapping each other, a certain bark-ness. In this case: on the contrary, slicing. Yet there exists one unifying element. The incessant sense of déjà $v u$, which accompanies the author in the least expected locations: in Stutthof, in Jerusalem, in Prague. Paradoxically, the blueness of a summer sky in the camp, which the eleven-year-old boy, later an adult, and finally an old man, cannot escape:

The only belonging blue overcoming every other colour, imprinted in my memory as the colour of summer, the colour of tranquillity, the colour of forgetting - momentary forgetting - is that colour of a Polish summer in 1944. And for that little boy who is part of that summer, all this will remain for all time as a touchstone of beauty, nonpareil in all the landscapes I have collected into myself and which I will probably be able to collect - how to put it, in a phrase - for all time. [...] there is no doubt that to here I will always return. This return, even if it is divorced from that sombre return from which there is no way out, is itself a return which has no way out. The colour is the colour of childhood, a colour of innocence, a colour of beauty. And this too is an immutable law from which there is no escape. There is no escape from beauty, from the sense of beauty at the height and in the midst of the Great Death which governs all (PMŚ, 110-111). 


\section{Conclusions}

By analogy to Marianne Hirsch's postmemory, in the case of the more recent Lager essays, one can talk about post-imagination, that which has occurred in the essay after Auschwitz, while by analogy to the category of auto(thanato) graphy (Derrida's, modified by Aleksandra Ubertowska) - about auto(thanato) imaginative.

If, however, postmemory is a category in which one is, as it were, tossed according to her/his generation, then post-imagination, imagination altered in essays (as well as in poetry) after Auschwitz (or, rather, more often - after Birkenau), proves an individual category, it requires an extreme individual effort, an effort pushing the borders of human intellectual capabilities.

In post-imagination, the camp is no longer equal to the term of anus mundi. No physiologically or eugenically understood "cleansing" occurs, nor, all the less, an ideological catharsis. Yet that rare moment, seized by Didi-Huberman, of the co-existence of the unimaginable, and its barely imaginable - also for the essayists themselves: of a record.

\section{Bibliography}

Améry Jean, Jenseits von Schuld und Sühne. Bewältigungsversuche eines Überwältigten, Szczesny Verlag, München 1966.

Améry Jean, Über das Altern. Revolte und Resignation, E. Klett, Stuttgart 1968.

Bartelski Lesław Marian, Cień wojny. Eseje, Czytelnik, Warsaw 1983.

Blanchot Maurice, Niezniszczalne. Być Żydem, trans. Wanda Błońska, Literatura na Świecie 1996, issue 10 , pp. $59-68$.

Claude Lanzmann, "Le non-lieux de la mémoire", in: Au sujet de Shoah, le film de Claude Lanzmann, Bernard Cuau (ed.), Belin, Paris 1990, pp. 280-293.

Claude Lanzmann's Shoah. Key Essays, Stuart Liebman, Oxford University Press, New York 2007. Conrad Joseph, Heart of Darkness, Penguin Books, London 1994.

Conrad Joseph, Jądro ciemności, trans. Magda Heydel, Znak, Krakow 2011.

Czapliński Przemysław, "Nie-miejsce" [entry] in: Modi memorandi. Leksykon kultury pamięci, Magdalena Saryusz-Wolska, Robert Traba (eds.), collaborator Joanna Kalicka, Scholar, Warsaw 2014, pp. 270-272.

Didi-Huberman George, Obrazy mimo wszystko, trans. Mai Kubiak Ho-Chi, Universitas, Krakow 2008.

Gajewska Agnieszka, Zagłada i gwiazdy. Przeszłość w prozie Stanistawa Lema, Wydawnictwo Naukowe UAM, Poznań 2016.

Jedlicki Jerzy, "Dzieje doświadczone i dzieje zaświadczone”, in: Dzieło literackie jako źródto historyczne, Zofia Stefanowska and Janusz Sławiński, Czytelnik, Warsaw 1978, pp. 344-371.

Kępiński Antoni, Refleksje oświęcimskie, selection and introduction Zdzisław Jan Ryn, Wydawnictwo Literackie, Krakow 2005.

Kielar Wiesław, Anus mundi, $3^{\text {rd }}$ edition, Wydawnictwo Literackie, Krakow 1980.

Kulka Otto Dov, Pejzaże metropolii śmierci. Rozmyślania o pamięci i wyobraźni, trans. Michał Szczubiałka, Czarne, Wołowiec 2014. 
Morawiec Arkadiusz, Literatura w lagrze, lager w literaturze. Fakt-temat-metafora, Wydawnictwo Akademii Humanistyczno-Ekonomicznej, Łódź 2009.

Snyder Timothy, Black Earth. The Holocaust as History and Warning, Tim Duggan Books, New York 2015.

Sofsky Wolfgang, Die Ordnung des Terrors. Das Konzentrationslager, S. Fischer, Frankfurt am Main 1993.

Ubertowska Aleksandra, Holokaust. Auto(tanato)grafie, Wydawnictwo IBL PAN, Warsaw 2014.

Wojdowski Bogdan, "Judaizm jako los", Puls 1993, issue 3, pp. 61-78.

Zimand Roman, Diarysta Stefan Ż., Ossolineum, Wrocław 1990.

Zonik Zygmunt, Anus belli. Ewakuacja i wyzwolenie hitlerowskich obozów koncentracyjnych, PWN, Warsaw 1988.

\section{Georges Didi-Huberman, Écorces, and Otto Dov Kulka, Landscapes of the Metropolis of Death - as Lager essays? Imagination and remembrance of the title formulations in relation to the formulation ,anus mundi”}

(Summary)

The article is an attempt at interpretation of two essays, which may be called „Lager” essays. These are Écorces written by G. Didi-Huberman and Landscapes of the Metropolis of Death written by O.D. Kulka, their books are deeply related as the negation or at least as the questioning of the title of autobiographical book Anus mundi written by W. Kielar. Both authors do not describe Nazi concentration camp as ,the anus of the world". Their imagination is a post-imagination, their memory is a post-memory. In her paper Kuczyńska-Koschany considers the condition of the essay as quasi-genre after the Holocaust, after the genocide and in reference to the experience of a Lager.

Key words: Lager essay; formulation ,anus mundi”; postimagination; postmemory; Georges Didi-Huberman; Otto Dov Kulka; Wiesław Kielar 